\title{
DRIED BIOGAS SLURRY AS A A NUTRIENT SOURCE IN GROWING PIG DIETS
}

\author{
V. RAVINDRAN AND A.S.B. RAJAGURU \\ Department of Animal Science, University of Peradeniya, \\ Peradeniya, Sri Lanka.
}

(Date of receipt : 12 October 1987)

(Date of acceptance : 15 March 1988)

\begin{abstract}
Two feeding experiments were conducted to evaluate the effects of including dried biogas slurry (DBS) on the performance of growing pigs. In each experiment, 36 growing pigs were limit-fed diets containing $0,5,10$, and $20 \%$ DBS substituted $(w / w)$ for coconut oil cake and rice bran. The results suggest that DBS is potentially useful as a nutrient source in growing pig diets. The inclusion of up to $10 \%$ DBS in diets had no adverse effect on gain and feed efficiency, whereas $20 \%$ DBS inclusion depressed performance which may be attributed to its high fibre and low available energy contents. The merits of biogas slurry over the raw manure and the practical limitations to its use are discussed.
\end{abstract}

\section{Introduction}

The need to develop renewable sources of energy has generated much interest during the recent decades in biogas production from animal manures. The slurry (solid by-product) from biogas digesters is generally utilized as a fertilizer for crops as in fish ponds. Because the biogas slurry contains moderate amounts of protein, ${ }^{7}$ it is possible that the dried slurry could be used as an animal feeding stuff.

Extensive reviews are available on the refeeding of various forms of animal manure, $, 4,5$ but corresponding data on the feeding value of biogas slurry is almost non-existent. The experiments reported herein were carried out to evaluate dried biogas slurry (DBS) as a source of nutrient in growing pig diets.

\section{Materials and Methods}

\subsection{Source of DBS}

The DBS samples used in this study originated from a continuosly-fed Indian-type field scale biogas digester maintained at the piggery of the University of Peradeniya. Fresh manure was washed daily into the digester from pigs housed in semi-open concrete-floored pens. The pigs were fed on a low-quality swill (8-10\% crude protein, $10-16 \%$ crude fibre) and limited quantities of a mixture of rice bran and coconut oil cake. The solid effluent from the digester was removed, initially sun-dried on a concrete floor to 86-88\% solids content and finally dried overnight in an Unitherm oven at 
$60^{\circ} \mathrm{C}$. The resultant hard crumbs were ground into a semi-powdery form before incorporation into the diets.

Prior to the commencement of each feeding trial, the DBS was bulked and representative samples were taken for the analysis of proximate components. ${ }^{1}$ Representative samples of rice bran and coconut oil cake were also subjected to similar analyses. ${ }^{1}$

\subsection{Feeding experiments}

The study consisted of two separate feeding experiments. In each experiment, thirty-six crossbred barrows were divided into three groups on the basis of weight. The average weight of pigs in Experiments 1 and 2 were 15.5 and $18.3 \mathrm{~kg}$, respectively. Pigs within each weight group were assigned to one of twelve pens, so that there were three pigs per pen. The four treatments were then randomly allocated to three pens each.

The composition of the experimental diets is shown in Table 1 . They were designed to contain $0,5,10$ and $20 \%$ DBS, the DBS replacing coconut oil cake and rice bran in the control diet. Each five parts of DBS replaced $(\mathrm{w} / \mathrm{w})$ three parts of coconut oil cake and two parts of rice bran. The diets were iso-nitrogenous but not iso-caloric since the digestible energy value of DBS was not available.

Pigs were housed in concrete-floored pens. The diets were limit fed twice daily in equal amounts. The amount of feed to be given was determined by the animal group consuming the least during a 30 -minute feeding period at each weighing. Feeding levels were held constant until next weighing. Body weights were recorded at weekly intervals. The experiments were of eight weeks duration. Diets were mixed with water immediately prior to feeding to improve consumption and to reduce wastage. Water was freely available at all times.

Average daily gain and feed to gain ratio were computed on a pen basis. The data were subjected to analysis of variance and the treatment means were compared using the 'Tukey's procedure. ${ }^{8}$ 
Table 1. Percentage composition of pig grower diets used in the feeding trials

\begin{tabular}{|c|c|c|c|c|}
\hline \multirow{2}{*}{. } & \multirow{2}{*}{ Control } & \multicolumn{3}{|c|}{ Level of DBS (\%) } \\
\hline & & 5 & 10 & 20 \\
\hline Maize & 25 & 25 & 25 & 25 . \\
\hline Coconut oil cake & 40 & 37 & 34 & 28 \\
\hline Rice bran & 25 & 23 & 21. & 17 \\
\hline DBS & - & 5 & 10 & 20 \\
\hline Fish meal ( $50 \% \mathrm{CP})$ & 6 & 6 & 6 & 6 \\
\hline Skim milk powder & 2 & 2 & 2 & 2 \\
\hline Bone meal & 1.5 & 1.5 & 1.5 & 1.5 \\
\hline Vitamin-trace mineral premix ${ }^{a}$ & 0.25 & 0.25 & 0.25 & 0.25 \\
\hline Salt & 0.25 & 0.25 & 0.25 & 0.25 \\
\hline \multicolumn{5}{|l|}{ Analysis (dry matter basis) } \\
\hline Crude protein $(\%)^{b}$ & 18.2 & 18.1 & 18.3 & 18.2 \\
\hline Digestible energy $(\mathrm{Mcal} / \mathrm{kg})^{\mathrm{c}}$ & 2.88 & - & - & - \\
\hline
\end{tabular}

${ }^{a}$ Supplied (per kilogram of premix): 6,600,000 IU vitamin $A, 528,000$ IU vitamin $D_{3}$, 880 IU Vitamin E, $1.98 \mathrm{~g}$ riboflavin, $4.4 \mathrm{~g}$ calcium panthothenate, $8.8 \mathrm{~g}$ niacinamide, $22.0 \mathrm{~g}$ choline chloride, $8.8 \mathrm{~g}$ vitamin $\mathrm{B}_{12}, 1.32 \mathrm{~g}$ vitamin $\mathrm{K}, 5.28 \mathrm{~g}$ manganese sulfate, $1.98 \mathrm{~g}$ copper carbonate, $0.99 \mathrm{~g}$ calcium iodate, $0.55 \mathrm{~g}$ cobalt sulfate and $0.22 \mathrm{~g}$ zinc oxide.

${ }^{b}$ Determined value.

${ }^{\mathrm{c}}$ Calculated value.

\section{Results and Discussion}

The compositional data of DBS confirm its moderate nutritional potential for non-ruminants (Table 2). The crude protein content of DBS samples used in Experiments 1 and 2 were 16.6 and 14.7\%, respectively. The crude fibre contents of the samples were however, high averaging $18.5 \%$. The high ash content was related to sand contamination, as indicated by the high levels of acid-insoluble ash. The blocking of biogas digesters by sand is a common practical problem and contamination with sand may be expected to be more severe under field situations. But preliminary observations have shown that considerable reduction in contamination could be achieved by 'scoop shovelling' instead of directly washing the manure into the biogas digester. 
Table 2. Average chemical composition of dried biogas slurry, coconut oil cake and rice bran (dry matter basis)

\begin{tabular}{|c|c|c|c|c|}
\hline \multirow{2}{*}{ Constituent } & \multicolumn{2}{|c|}{ Dried biogas slurry } & \multirow{2}{*}{$\begin{array}{l}\text { Coconut } \\
\text { oil cake }\end{array}$} & \multirow{2}{*}{$\begin{array}{l}\text { Rice } \\
\text { bran }\end{array}$} \\
\hline & Trial 1 & Trial 2 & & \\
\hline Crude protein (Nx6.25) & 16.6 & 14.7 & 21.0 & 10.5 \\
\hline Ether extract & 3.1 & 3.3 & 8.6 & 11.2 \\
\hline Crude fibre & 18.5 & 18.4 & 12.1 & 16.8 \\
\hline Ash & 11.4 & 13.5 & 6.9 & 12.5 \\
\hline Nitrogen-free extract & 50.4 & 50.1 & 51.4 & 49.0 \\
\hline Acid-insoluble ash & 6.1 & 8.2 & 0.6 & 5.1 \\
\hline . & & & & \\
\hline
\end{tabular}

The potential of biogas slurry as a non-ruminant feedstuff has been questioned by Summers et al. ${ }^{9}$ on the grounds that a well digested slurry will have minimal 'potentially' digestible carbohydrates left. The DBS samples used in the present study contained an average of $50.2 \%$ nitrogen-free extracts, which is generally assumed to be indicative of the digestible carbohydrate fraction.

The variable nature of biogas slurry needs special mention at this point. As could be expected, the composition of slurry would vary depending on the source of manure (animal species) which, in turn, would differ widely according to the type of diet fed to the donor animals. For example, preliminary evaluation of biogas slurry from cattle manure have shown it to be a poor quality feed for non-ruminants containing crude protein contents of less than $9 \%$ and crude fibre contents as high as $31 \%{ }^{7}$

In Experiment 1, the performance of animals fed diets containing 5 and $10 \%$ DBS were similar to those on the control diet (Table 3). But the performance tended to be non-significantly $(\mathrm{P}>0.05)$ higher at $5 \%$ DBS. The significance of this slight growth response is unclear. Although pigs fed diets with $20 \%$ DBS gained $11 \%$ slower and required $12 \%$ more feed per unit of gain than did controls, the differences were not statistically significant.

In Experiment 2, the performance of pigs were unaffected by the dietary inclusion of up to 10\% DBS (Table 3). Gain and feed efficiency of pigs fed diets with $20 \%$ DBS, however, were significantly poorer $(\mathrm{P}<0.05)$ when compared to other treatments. 
Table 3. Performance of growing pigs fed diets containing varying levels of DBS

\begin{tabular}{|c|c|c|c|c|}
\hline & $\begin{array}{l}\text { Avg. initial } \\
\text { weight }(\mathrm{kg})\end{array}$ & $\begin{array}{l}\text { Avg. final } \\
\text { weight }(\mathrm{kg})\end{array}$ & $\begin{array}{l}\text { Avg. daily } \\
\text { gain }(\mathrm{kg})\end{array}$ & $\begin{array}{c}\text { Feed } \\
\text { per gain }\end{array}$ \\
\hline \multicolumn{5}{|l|}{ Experiment 1} \\
\hline Control & 15.4 & 31.1 & $0.28^{\mathrm{ab}}$ & $3.7 .9^{\mathrm{ab}}$ \\
\hline $5 \% \mathrm{DBS}$ & 15.6 & 32.6 & $0.30^{\mathrm{a}}$ & $3.53^{\mathrm{a}}$ \\
\hline $10 \% \mathrm{DBS}$ & 15.4 & 31.1 & $0.28^{a b}$ & $3.79^{\mathrm{ab}}$ \\
\hline $20 \% \mathrm{DBS}$ & 15.5 & 29.5 & $0.25^{b}$ & $4.24^{\mathrm{b}}$ \\
\hline SEM* & 0.31 & 0.60 & 0.02 & 0.14 \\
\hline \multicolumn{5}{|l|}{ Experiment 2} \\
\hline Control & 18.2 & 37.2 & $0.34^{\mathrm{a}}$ & $3: 37^{\mathrm{a}}$ \\
\hline $5 \% \mathrm{DBS}$ & 18.2 & 37.8 & $0.35^{\mathrm{a}}$ & $3.27^{\mathrm{a}}$ \\
\hline $10 \% \mathrm{DBS}$ & 18.4 & 38,0 & $0.35^{\mathrm{a}}$ & $3.37^{a}$ \\
\hline $20 \% \mathrm{DBS}$ & 18.3 & 35.1 & $0.30^{\mathrm{b}}$ & $3.82^{\mathrm{b}}$ \\
\hline $\mathrm{SEM}^{*}$ & 0.42 & 0.72 & 0.02 & 0.12 \\
\hline
\end{tabular}

* Standard error of mean.

a,b Within each trial, means in the same column with different superscripts are significantly $(\mathrm{P}<0.05)$ different.

The weight gains of animals in Experiment 1 were markedly lower than those in Experiment 2. Reasons for this difference are unclear, but may have been due to the extremely hot weather experienced during the experimental period.

The overall results suggest that DBS could be used as a nutrient source in growing pig diets up to $10 \%$ level without any adverse effect on growth performance. The pigs appear to have the ability to extract the benefits of microbial protein and vitamin B-complex up to this level of inclusion. A very high content of vitamin $\cdot B_{12}(3000 \mathrm{mcg} / \mathrm{kg})$ in DBS has been reported. ${ }^{2}$ The growth depression observed on $20 \%$ DBS diets is probably related to the low available energy content, resulting from its high crude fibre content. It is known that animal manures have a low digestible energy content. ${ }^{3,4,5}$. The available energy could be expected. to further lowered during the production of biogas. ${ }^{6}$ Thus the low energy content of DBS would be a major factor limiting its high level usage in non-ruminant diets. From the energy point of view, ruminants are the most desirable species for feeding biogas slurry because of the ability of the rumen microbes to utilize fibre components.

The digested slurry has several advantages over the raw manure. The slurry has only a faint odour and is greatly improved in this respect over the 
manure. The slurry. is also stable on long-term storage. A potential health hazard due to the survival of pathogens in DBS does exist, but studies have demonstrated that anaerobic digestion considerably reduces the number of pathogens present in animal manures. ${ }^{9}$ No health problems were observed in pigs in the present study.

While DBS is potentially useful as a feedstuff for growing pigs, utilization of this material requires some artificial dehydration. Even under sunny and dry weather conditions, sun-drying was found to reduce the moisture content of the slurry to only $12-14 \%$. Cheaper ways of drying the slurry need be evolved before its practical use can be encouraged. An additional factor of concern is the possible wide variability in the chemical composition of the slurry. Considerable variations have been reported with regard to the crude protein (14.9-18.2\%), crude fibre (17.4-26.4\%) and ash (11.2-20.0\%) contents of DBS samples. ${ }^{7}$ This would prevent any general recommendation regarding the potential use of slurry in animal diets.

\section{Acknowledgement}

The study was partly funded by the International Foundation of Science, Sweden. Financial assistance was also provided through an FAO grant on 'non-traditional feedstuff evaluation'.

\section{References}

1. AOAC (1970) Official Metbods of Analysis, 11th edition. Association of Official Analytical Chemists, Washington, D.C.

2. MADAMBA, F.D. (1978) Riogas and Waste Recycling: The Philippine experience, pp. 159-164, Manila: Maya Farms.

3. MARTIN, J.H., LOEHR, R.C. \& PILBEAM, T.E. (1983) Agric. Wastes. 6 : 131-166.

4. MARTIN, J.H., LOEHR, R.C. \& PILBEAM, T.E. (1983) Agric. Wastes 6 : 193-220.

5. MARTIN, J.H., LOEHR, R.C. \& PILBEAM, T.E. (1983) Agric. Wastes. 7 : 81-110.

6. PRIOR, R.L. \& HASHIMOTO, A.E. (1982) In Fuel gas production from biomass. pp. 215-235, Boca Raton, Florida: CRC Press, Inc.

7. RAVINDRAN, V. (1987) New feed resource in Sri Lanka. Progress report submitted to International Foundation of Science, Sweden (unpublished).

8. STEEL, R.G.D. \& TORRIE, J.H. (1960) Principles and procedures of Statistics. New York: McGraw-Hill Book Co., Inc.

9. SUMMERS, R., BOUSFIELD, S. \& HOBSON, P.N. (1980) In Anaerobic digestion, Pp. 409-414, London: Applied Science Publishers Ltd. 